\title{
O Turismo de Base Comunitária em uma comunidade ribeirinha da Amazônia: O Caso de Anã na Reserva Extrativista Tapajós-Arapiuns, Santarém (PA)
}

\author{
The Tourism Community Based on a riverside community of \\ the Amazon: The Case of Anã in Extractive Reserve Tapajos- \\ Arapiuns, Santarém (PA, Brazil)
}

Elcivânia de Oliveira Barreto, Maria Goretti da Costa Tavares

\begin{abstract}
RESUMO
Este artigo visou analisar a relação do turismo de base comunitária e o uso do território na comunidade ribeirinha de Anã no município de Santarém, estado do Pará. Sendo assim, neste artigo, trazemos uma breve análise do turismo de base comunitária desenvolvido em Anã, uma comunidade ribeirinha situada em uma unidade de conservação localizada no município de Santarém, denominada de Reserva Extrativista Tapajós-Arapiuns. Neste estudo, ainda levamos em consideração o papel do Estado e da ONG Projeto Saúde e Alegria na produção do espaço para o TBC. Desta forma, realizamos uma revisão bibliográfica sobre TBC, Estado e Terceiro Setor, fundamental para subsidiar a realização do trabalho de campo. Destarte, partimos da premissa que o turismo de base comunitária é um contraponto ao turismo convencional, por assim dizer uma contra-racionalidade hegemônica. E é dentro dessa abordagem, que identificamos que o turismo de base comunitária desenvolvido em Anã, ainda não se configura como uma contra-racionalidade, uma vez que a ONG PSA atua com hegemonia frente ao turismo de base comunitária, e isso se perpetua principalmente pelas ações e inações do Estado na comunidade ribeirinha de Anã.

PALAVRAS-CHAVE: Turismo de Base Comunitária; Comunidade Ribeirinha de Anã; Estado; ONG Projeto Saúde e Alegria.
\end{abstract}




\section{ABSTRACT}

This article aimed to analyze the relationship of community-based tourism and the use of land in the riverside community of Anã in the municipality of Santarém, state of Pará. So in this article we bring brief analysis of community-based tourism developed in Anã, a riverside community located in a protected area in the municipality of Santarém, called Extractive Reserve Tapajos-Arapiuns. This study also took into account the role of the state and the NGO Projeto Saúde e Alegria PSA in the production of space for TBC. Thus, we conducted a literature review of TBC, State and Third Sector, critical to support the preparation of field work. Thus, we assume that the community-based tourism is a counterpoint to conventional tourism, so to speak a hegemonic counter-rationality. And it is within this approach, we identified that the community-based tourism developed in Anã, is not yet configured as a counter-rationality, since the PSA NGO operates with front hegemony to community-based tourism, and this is mainly perpetuated by actions and inactions of the State in the riverside community Anã.

KEYWORDS: Community Based Tourism; riverside community of Anã; State; NGO Projeto Saúde e Alegria.

\section{Introdução}

O presente artigo traz alguns dos resultados que apresentamos em nossa dissertação de mestrado desenvolvida durante o curso de PósGraduação em Geografia, esta concluída no ano de 2015. Nesse sentido, este artigo busca analisar o turismo de base comunitária desenvolvido em uma comunidade ribeirinha da Amazônia, esta denominada Anã, a qual localiza-se na Reserva Extrativista Tapajós-Arapiuns, no município de Santarém, estado do Pará. Nossa pesquisa de campo foi realizada no ano de 2014, e buscamos compreender melhor a prática de turismo de base comunitária desenvolvida na comunidade, entendendo nesse processo o papel do Estado, da ONG Saúde e Alegria e da própria comunidade, fundamentais no processo de produção do espaço no que se refere a prática de TBC em Anã.

O Turismo de Base Comunitária é entendido como uma prática que se contrapõe ao turismo convencional ou mais precisamente ao turismo de massas. Segundo alguns autores que discutem o TBC no Brasil, dentre os quais Bartholo, (2009) que diz que o TBC busca estabelecer um sentido real de comunidade, em que as experiências do lugar, o modo de vida da população são compartilhadas com os visitantes. Está para além de uma relação baseada em trocas comerciais, em que prevalece não apenas a dimensão econômica, mas a dimensão social, circunscrita numa perspectiva de maior autonomia das populações envolvidas no processo, propiciando assim o aumento da justiça social e da qualidade de vida, consolidando de fato um desenvolvimento territorial pleno.

Diante disso, além da pesquisa de campo, realizamos a priori pesquisa bibliográfica e documental, imprescindíveis para o entendimento das categorias de análises tomadas neste estudo. Além de revisão e análise bibliográficas sobre o TBC, buscamos autores que nos auxiliassem no entendimento de Estado e Terceiro Setor. Desta forma, além de uma breve

Revista Brasileira de Ecoturismo, São Paulo, v.10, n.3, ago-out 2017, pp. 579-611. 
reflexão teórica sobre turismo de base comunitária, este artigo traz reflexões teóricas e conceituais sobre o Estado e Terceiro Setor, buscando relacionálos com o nosso objeto de estudo.

\section{Reflexões Teóricas Sobre o Turismo de Base Comunitária}

O turismo em cenário mundial é comandado por uma lógica do Mercado Global, no qual agentes hegemônicos, como Estado e Mercado, ditam as regras do fazer turístico e juntos impregnam na sociedade a falácia de que o turismo é crucial para o desenvolvimento socioeconômico, bem como é a saída para as disparidades sócio-espaciais do atual meio técnicocientifico e informacional.

Pensar o turismo de base comunitária como um contra-movimento é, sem dúvida, uma tarefa árdua, levando em conta o contexto no qual está inserido, no meio de um movimento global, que como já exaustivamente mencionado privilegia agentes hegemônicos, como empresas nacionais e multinacionais, que além de promoverem uma fragmentação do território, juntas vão se coadunando com vistas a uma privatização do território, negligenciando o fato de que o turismo não se dá em porções do território vazias, sejam vazias de objetos ou ações.

Diante disso, daremos evidência ao turismo de base comunitária, partindo do pressuposto que este é uma forma de contra-racionalidade hegemônica de pensar o turismo. Contudo, não se pode negar que ainda estamos em busca de respostas e de instrumentos que nos permitam afirmar isso, conquanto, esperamos obter tais respostas a partir do nosso objeto de estudo, que tem como recorte espacial a comunidade ribeirinha de Anã, no município de Santarém.

O turismo tem-se destacado no mundo contemporâneo como uma das atividades econômicas mais promissoras, apresentando um alto grau de desenvolvimento. Dados da Organização Mundial do Turismo - OMT apontam que no ano de 2012 a chegada de turistas internacionais ultrapassou a casa de um bilhão, atingindo assim um crescimento de $4 \%$. No ano de 2013, esse crescimento alcançou os 5\%, o qual correspondeu a 52 milhões de chegadas de turistas a mais em relação ao ano anterior (OMT, 2013).

Entre os anos de 1995 e 2013, a chegada de turistas internacionais cresceu em torno de 550 milhões, alcançando assim o recorde em 2013, com a chegada de 1087 bilhões de turistas. Tais dados revelam que nem mesmo a instabilidade econômica mundial impossibilitou o crescimento da atividade turística, pelo contrário, a mesma vem sofrendo uma grande evolução, demonstrando uma notável capacidade de adaptação, conforme ressalta o Secretário Geral da OMT, Taleb Rifai:

El sector turístico ha demostrado una notable capacidad de adaptación a las condiciones cambiantes de los mercados, así como para impulsar el crecimiento y la creación de empleo en todo el mundo, a pesar de los retos económicos y geopolíticos que persisten. De hecho, el turismo ha sido uno 
de los pocos sectores que ha aportado buenas noticias a muchas economias ${ }^{1}$.

É possível considerar, a partir das informações fornecidas pela OMT (2014), que o turismo se constitui como um instrumento possível de promover o desenvolvimento econômico, desta forma, apontam-na como uma das atividades econômicas mais promissoras, o qual vem contribuindo veementemente para a economia mundial, sintonizando a geração de emprego e renda, alcançando patamares na balança comercial mundial. Com isso, pode-se ratificar aquela velha concepção de turismo, enquanto panaceia principalmente das economias estagnadas de alguns países, fator que leva de imediato à corrida de instituições públicas e privadas a valorizar esta atividade em suas economias.

Longe, no entanto, de ser uma panaceia, o turismo tem se configurado como uma atividade dicotômica, pois ao mesmo tempo em que transforma lugares em territórios turísticos com a finalidade de desenvolvêlos economicamente e socialmente, a atividade tem a capacidade de provocar profundas transformações territoriais que afetam diretamente 0 modo de vida, a memória, a própria identidade das populações desses territórios.

Ao observarmos os dados apresentados pela OMT, podemos dizer que a atividade turística é vista apenas como uma grande mola propulsora de desenvolvimento econômico, quanto mais se elevam os números de chegadas de turistas internacionais, mais a atenção se volta para a atividade. Pode-se dizer com isso, que o turismo [...] "tem seu crescimento coordenado e orientado pelo mercado e pelos interesses dos grandes capitais nacionais e internacionais, sem considerar, de maneira apropriada, os demais atores envolvidos no processo" (BARRETO, 2000, apud MENDONÇA, 2004). Isso fez e faz com que o Mercado exerça certo domínio sobre a população de algumas localidades, tornando a atividade turística excludente, uma vez que se desenvolve sem levar em consideração os interesses endógenos do lugar.

Parece, portanto, haver um paradoxo a ser considerado nesta reflexão. Apesar do potencial do turismo enquanto alternativa para a redução das desigualdades sociais e combate à pobreza, o enfoque de planejamento para o setor, prioritariamente centrado na perspectiva de desenvolvimento econômico, está ainda ancorado em uma lógica de mercado, que prioriza o lucro e o rápido retorno dos investimentos. Como resultado, o turismo tem sido também, frequentemente, um veículo significativo de impactos negativos sobre os destinos nos quais se desenvolve, contribuindo para o agravamento do processo de exclusão social (SANCHO; IRVING, 2011, p. 45). 
Desta forma, pensando na inclusão da população local no processo de desenvolvimento do turismo, surgiram algumas modalidades de turismo, dentre estas o turismo de base comunitária, uma modalidade recente do turismo, que vem se configurando gradativamente em cenário nacional e também mundial.

Tem-se assim um contraponto ao turismo convencional, que se trata do turismo de base comunitária, que visa não apenas o lucro, nem tão pouco os interesses de agentes hegemônicos, mas que traz em seu bojo princípios que possibilitam o fomento da atividade pautada no desenvolvimento local. Pensar o turismo como uma alternativa economicamente viável ao desenvolvimento local é vislumbrar sem dúvida a melhoria da qualidade de vida da população.

No que se refere ao turismo de base comunitária, constatamos que ainda existe pouca produção teórica, no entanto, tal prática tem despertado o interesse de vários estudiosos, principalmente ligados a área da geografia, incitando a produção de pesquisas em lugares que vêm desenvolvendo esta modalidade de turismo.

Diante das várias experiências de TBC no país e no mundo, diversificam-se também as terminologias e conceitos sobre tal modalidade, 0 que não quer dizer que seja um problema, mas sim um desafio para extrair de tais experiências suas especificidades e suas contribuições para a formulação de um aporte teórico sobre o TBC, bem como a formulação de políticas públicas de turismo que vislumbrem justamente o olhar, a inserção da população local.

Levando em consideração a diversidade de experiências, identificamos algumas denominações que esta modalidade assume tanto na práxis como na literatura, os quais sejam: turismo comunitário, ecoturismo de base comunitária, turismo responsável, turismo rural comunitário, turismo justo, turismo solidário, dentre outras. Sendo assim apresentaremos a seguir reflexões de alguns autores que tem contribuído para a construção e 0 fortalecimento de um aporte teórico em torno da temática.

Cito inicialmente o conceito de ecoturismo de base comunitária apresentado por Mitraud (2003), o qual parte de uma perspectiva de turismo responsáve2. Sendo assim, este seria o tipo de "turismo realizado em áreas naturais, sendo determinado e controlado pelas comunidades locais, que gera benefícios predominantemente para estas e para as áreas relevantes para a conservação da biodiversidade" (MITRAUD, 2003, p. 23). Vale ressaltar que este conceito se encontra no Manual de Ecoturismo de Base Comunitária elaborado pela WWF ${ }^{3}$ no ano de 2003. Este manual apresenta algumas possíveis metodologias de desenvolvimento do ecoturismo no Brasil, uma vez que se vivenciava um período de desalento com a atividade turística tendo em vista os seus impactos negativos acarretados principalmente às áreas naturais e às populações residentes.

Utilizando a mesma terminologia, "ecoturismo de base comunitária", a ONG CEAPS/ Projeto Saúde é Alegria refere-se á prática como uma nova forma de gerir o turismo com ênfase no ser humano e nas relações com o 
outro. Visando a geração de renda em comunidades ribeirinhas da região, a ONG propôs o projeto de Ecoturismo de Base Comunitária, que parte de uma perspectiva de turismo que

[...] propõe um modelo de desenvolvimento que privilegie o ser humano, que garanta condições de vida digna a todos os cidadãos, centrado em uma cultura de cooperação, parceria e solidariedade. [...] pretendendo ser antes de tudo um momento de encontro entre pessoas e culturas diferentes e este elemento precisa ser resgatado com muita ênfase, com todas suas implicações, para sair da lógica restrita e mercantilista do turismo de massa (ONG PROJETO SAÚDE E ALEGRIA, 2011).

Observa-se, nesse sentido, que o conceito apresentado pela ONG enfatiza uma contraposição ao turismo de massa, uma vez que privilegia as experiências vivenciadas tanto pelo residente quanto pelo visitante, uma experiência no e com o lugar, portanto busca-se não a fragmentação dos lugares, tão pouco a exclusão do feio, muito menos afastar o turista do pobre, do usual, conforme ressalta Carlos ao tratar do turismo contemporâneo, mas propor uma nova forma de turismo que valorize 0 lugar, as relações existentes, as experiências vividas neste lugar.

No âmbito do Estado, mais precisamente do Ministério do Turismo, Órgão Oficial do Turismo no Brasil, o turismo de base comunitária, denominado ainda de solidário, de conservação, entre outras denominações, se configura como:

modelo alternativo de desenvolvimento turístico, baseado na autogestão, no associativismo/cooperativismo, na valorização da cultura local e, principalmente, no protagonismo das comunidades locais, visando à apropriação por parte destas dos benefícios advindos do desenvolvimento da atividade turística (BRASIL, MTUR, 2008).

Convém destacar o conceito apresentado pela Rede Cearense de Turismo Comunitário - Rede Tucum ${ }^{4}$, o qual utiliza a terminologia turismo comunitário, e diz que este, nasce da percepção das próprias comunidades em relação ao turismo, que insatisfeitas com um modelo de desenvolvimento turístico pautado na concentração de renda e na geração de problemas socioambientais, passaram a requerer para si uma autonomia frente a atividade turística em seus territórios, redesenhando assim um turismo que vai "na contramão do convencional, pois a população local passa a ter o controle efetivo do planejamento das atividades e pela gestão das infraestruturas e serviços turísticos" (REDE TUCUM, 2013). 
No site da Rede Tucum são apresentados ainda princípios e diretrizes que regem o turismo comunitário no Ceará, quais sejam:

1. As atividades de turismo são desenvolvidas por grupos organizados e os projetos são coletivos, de base familiar;

2. O turismo se integra à dinâmica produtiva local, sem substituir as atividades econômicas tradicionais;

3. O planejamento e a gestão das atividades são de responsabilidade da organização comunitária local;

4. O turismo comunitário baseia-se na ética e na solidariedade para estabelecer as relações comerciais e de intercâmbio entre a comunidade e os visitantes;

5. O turismo comunitário promove a geração e a distribuição equitativa da renda na comunidade;

6. O turismo comunitário fundamenta-se na diversidade de culturas e tradições, promovendo a valorização da produção, da cultura e das identidades locais;

7. O turismo comunitário promove o relacionamento direto e constante entre grupos que também desenvolvem a experiência de um turismo diferente, estabelecendo relações de cooperação e parceria entre si;

8. O turismo comunitário fundamenta-se na construção de uma relação entre sociedade, cultura e natureza que busque a sustentabilidade socioambiental. (REDE TUCUM, 2013).

Tais princípios e diretrizes nos remetem ao conceito de turismo comunitário elaborado por Coriolano, esta que tem desenvolvido de forma exponencial estudos sobre a temática em comunidades litorâneas no Estado do Ceará.

O turismo comunitário é aquele em que as comunidades de forma associativa organizam arranjos produtivos locais, possuindo o controle efetivo das terras e das atividades econômicas associadas à exploração do turismo. Nele o turista é levado a interagir com o lugar e com as famílias residentes, seja de pescadores, ribeirinhos, pantaneiros ou de índios (CORIOLANO, 2009, p. 282).

Privilegia-se assim a escala humana (CORIOLANO, 2003), pois é onde de fato o turismo comunitário deve concretizar-se, portanto, ocorre sobre o olhar atento das populações locais, que passam a atuar diretamente no desenvolvimento da atividade.

Para Maldonado (2009), o Turismo Rural Comunitário (terminologia utilizada pelo referido autor) surge principalmente como uma forma de resistência das populações locais em seus territórios, uma forma de resistir às intensas transformações impostas pelo processo de globalização ao seu lugar. 
O turismo de base comunitária, nesse sentido, "deve favorecer a coesão e o laço social e o sentido coletivo de vida em sociedade, e que por esta via, promoverá a qualidade de vida, o sentido de inclusão, a valorização da cultura local e o sentimento de pertencimento" (IRVING, 2009, p. 112).

O turismo de base comunitária nos permite desta forma repensar 0 sentido do lugar, partindo de uma reflexão "da maneira como as pessoas vivem nos lugares onde residem ou os que visitam, deles extraindo uma experiência" (CLAVAL, 2001 apud MARANDOLA, p.78).

O turismo de base comunitária, segundo Bartholo (2009, p.45), invoca um sentido de proximidade, o qual dialoga com o sentido do lugar heiddegeriano, uma vez que "[...] o lugar heideggeriano encaminha ao encontro face a face no vigor da proximidade. Nele a centralidade do encontro face a face não é meramente topológica”.

Diante disso, Bartholo (2009), discorre sobre o sentido de proximidade relacionando-o com as ideias da relação Eu-tu de Martin Buber, levando em conta que "a pessoa da relação Eu-Tu é o suporte relacional que permite fazer da alteridade uma presença, numa possibilidade relacional que se estende para além do campo do inter-humano". O resgate do sentido de proximidade se dá em decorrência da própria negação do sentido de proximidade que se tem observado nos dias atuais, no contexto de uma sociedade que vive em "tempos líquidos", no qual a valorização da relação Eu-Isso, se dá em detrimento da Eu-tu. Vale frisar que na relação Eu-Isso "não há lugar para proximidades vinculares, que lhe permanecem uma exterioridade. Ela não conhece encontros face a face [...]" (BARTHOLO, 2009, p. 51).

Portanto, o turismo de base comunitária permite um sentido de proximidade, que se concretiza nas experiências vividas e compartilhadas entre nativos e viajantes, ambos se permitem "uma atitude dialógica, o que significa a abertura para primordialmente falar com alguém, não de alguém ou alguma coisa" (BARTHOLO, 2009 p. 52).

Isso, indubitavelmente refletirá o desenvolvimento da atividade respeitando os valores de cada agente envolvido no processo, além do que induzirá não a literal comercialização dos patrimônios cultural e natural, mas a um momento em que haverá segundo Zaoual (2009) intercâmbio intercultural, assegurando também as durabilidades sociais e ecológicas.

Não se comercializam o que os turistas desejam; se disponibiliza o que entende ser valoroso, em termos culturais e ambientais. $O$ intercâmbio, as relações são 0 princípio fundamental do TBC. Assim como quem busca, está aberto a se adaptar e valorizar os códigos dos lugares visitados. Trata-se, portanto de um turismo que tem nas relações de hospitalidade a principal motivação. Entretanto, não se exclui o contrato. As relações econômicas são enriquecidas por outras relações que ultrapassam a racionalidade do lucro imediato (BURSZTYN; SANSOLO, 2010 p. 150) 
Vale ressaltar que isso só será possível mediante a participação ativa da população local principalmente no que condiz ao planejamento e gestão da atividade, conforme destaca Irving (2009). Isso demonstra o diferencial do turismo de base comunitária das demais modalidades de turismo que existem, em que se tem como foco não a dimensão econômica, mas a dimensão social, circunscrita numa perspectiva de maior autonomia das populações envolvidas no processo, propiciando assim o aumento da justiça social e da qualidade de vida, consolidando de fato um desenvolvimento territorial pleno.

Para tanto, vale destacar Irving (2009), ao elencar as premissas para o turismo de base comunitária, como forma de propor uma reflexão em torno deste, que possa vir a ultrapassar o sentido de "comunitário" e principalmente "comunidade", que na maioria das vezes são remetidos, ou tidos como sinônimos de pessoas carentes, de baixa renda, e por assim também exclusos das políticas de Estado, e/o relegados a segundo plano em tais políticas:

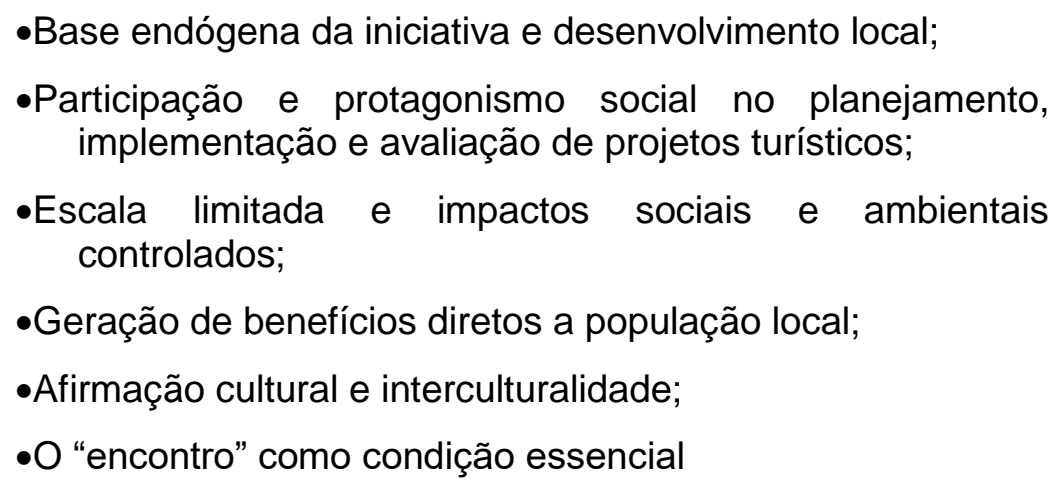

Tais premissas revelam a importância da população local nesse processo, em que não será o mercado a ditar as regras de o quê, como implementar o turismo em seu local. Trata-se de fato da presença dos atores locais durante todo o processo do planejamento da atividade até mesmo na execução da atividade, promovendo o desenvolvimento local a partir da iniciativa própria do local, firmando-os em seu território, em sua identidade, e fazendo do "encontro" com o turista, o seu principal "objetivo", este que deve corresponder:

no compromisso ético, de respeito, e engajamento de quem está de quem vem e o intercambio real entre os sujeitos que recebem e os que são recebidos e destes, com o ambiente no qual interagem (...) nesse sentido atores locais, e turistas são simultaneamente, agentes, sujeitos e objetos no processo. (IRVING, 2009, p. 116-117).

Além disso, com o TBC é revelado um novo perfil do turista, pois nesse caso não é o turista convencional que procura por experiências como estas, mas são turistas que, tomados de uma percepção de mundo 
diferenciada, em que se volta a conhecer e se mergulhar no outro, num modo diferente, que lhes permita vivenciar costumes, modos de vida totalmente diferentes do seu, mas que também se permita transmitir suas experiências enquanto não pertencente ao local visitado. Esse novo perfil de turista, revela a importância dessas populações excluídas pelo turismo convencional, mas que possibilitam a inserção delas num segmento em que não é a lógica nem o "tempo" do mercado que prevalece, mas a lógica, o "tempo" de comunidades seja tradicional ou não, que estabelecem e se firmam com uma nova proposta de turismo, que faz do encontro entre turistas e visitados, um processo, uma descoberta, crítica e reinvenção de uma nova realidade (IRVING, 2009).

Conforme podemos observar, há uma gama de denominações e caraterísticas que num esforço em conjunto buscam designar o turismo de base comunitária. Contudo, fez-se necessário optarmos por uma terminologia, o qual conduziu-nos na análise do nosso objeto de estudo.

Assim, utilizamo-nos, neste trabalho, da terminologia turismo de base comunitária, assim como nos assentamos nas premissas do TBC propostas por Irving (2009), as quais nos permitiram refletir o TBC enquanto possibilidade de uma comunidade, seja esta tradicional, ou não, firmar-se em seu território; direcionar o uso do seu território seja este para o turismo ou não; ter autonomia no processo de planejamento, execução e monitoramento da atividade; e de proporcionar um desenvolvimento, que corresponda de fato a uma mudança social positiva; tornando-os de fato verdadeiros cidadãos.

Mas, ainda trataremos o TBC como um contraponto ao turismo convencional, utilizando Santos (2012b) buscaremos analisá-lo como uma contra-racionalidade hegemônica, no qual se busca a essência nas relações entre os sujeitos, essa busca, que se configura como "um movimento sem fim que inclui o sujeito em um processo dialético e o restitui a si mesmo", e que faz restaurar a individualidade adormecida num período histórico em que o "êxito" é norma essencial da vida.

\section{Qual o Papel do Estado?}

A discussão sobre o Estado não é recente, contudo na Geografia ganhou força principalmente nas discussões da Geografia Política, consolidadas com Ratzel no século XIX, o qual toma como referência, principalmente, a consolidação dos Estados na Europa, mais precisamente na Alemanha, que em situação mais peculiar, vivenciava disputas territoriais com a finalidade de estabelecer a unificação dos Estados germânicos (Castro, 2009). Ratzel ainda sofrera influências das teorias darwinista, através das ideias de seu mentor, o viajante e etnógrafo Moritz Wagner (SEEMANN, 2012). Tais referências levaram Ratzel a elaborar sua acepção de Estado como um organismo, elencando o solo, como elemento crucial para a formação de um Estado forte, conforme se observa a seguir:

Revista Brasileira de Ecoturismo, São Paulo, v.10, n.3, ago-out 2017, pp. 579-611. 
(...) o Estado constitui-se como organismo ligado a uma fração determinada da superfície da terra, de modo que as suas propriedades se originam das do povo e do solo. (...). O Estado é um organismo não somente porque articula a vida do povo sobre a fixidez do solo, mas porque esta relação reforça-se por reciprocidade, ao ponto que formam não mais do que um único ser e que não se possa mais pensar em um sem o outro. (RATZEL, 1987, p. 61, tradução PFRIMER, 2011, p. 52).

Contudo, tal relação não é simples, pois repercute diretamente a relação do povo com o solo, relação que se dá a partir de "motivações religiosas e nacionais, lembranças históricas, vontade de potência de um indivíduo" e são motivações como estas, que dão origem aos Estados, mais precisamente ao Estado-Nação, pois Ratzel acreditava que somente a partir da criação simbólica, do sentimento de pertencimento do povo com o solo, é que poderia haver o fortalecimento do Estado, no que se refere à Alemanha do século XIX, esta "só realizaria seu destino de potência para fazer frente a outras potências europeias, através da consolidação duradoura da reunificação germânica (...). Mas, isto só seria possível com a adesão do povo a ideologia do nacionalismo" (CASTRO, 2009, p. 73-74, grifo do autor).

Conforme mencionam Costa (2013) e Castro (2009), Ratzel foi um dos clássicos da Geografia Política, assim como um dos expoentes na elaboração de uma densidade teórica sobre o Estado no âmbito da geografia, porém cabe lembrar Costa (2013, p. 257-261), quando se tenta formalizar uma teoria de Estado absoluto,

\begin{abstract}
Não é produtivo o debate sobre o 'caráter absoluto do Estado', (...), pois esse modo de organização política só pode ser compreendido à luz das sociedades históricoconcretas, o que elimina a possibilidade de uma ideia universal a seu respeito. (...). Isto não significa, por outro lado, a impossibilidade total da teoria, mas apenas a necessidade de que o conhecimento da estrutura estatal deverá dar-se em consonância com as determinações históricas. (...) Fica afastada assim, a possibilidade de uma 'estrutura geral' do Estado moderno, por mais que algumas de suas funções no interior da sociedade aparentemente se repitam de lugar para lugar e ao longo do tempo.
\end{abstract}

Sendo assim, o Estado não desapareceu, continua presente, assumindo no contexto da globalização novos contornos, que passam a legitimar um novo comportamento deste mediante os desafios impostos pelo período técnico-cientifico e informacional. Um dos elementos fundamentais nesse novo contexto que formaliza uma nova configuração do Estado é, sem dúvida, a "força" que este antes detinha, pois com a globalização a sua atuação enquanto ator hegemônico passa a dar lugar a atuação de outros atores, mais precisamente passa a atuar de forma dialética com novos 
atores. A função do Estado é remodelada, passando a assumir novos papéis, tornando-o tão ou mais necessário para a expansão de territorialidades hegemônicas, que passaram a ganhar foco a partir da década de 1970 e que se consolidaram pós Guerra Fria, com a era do neoliberalismo.

Podemos afirmar, que o papel do Estado tem-se reformulado e vem reformulando-se em cada período histórico, considerando, sobretudo a sua força de atuação, levando em consideração os fatores internos e externos ao território, assim como os atores hegemônicos em cada período. Desde o surgimento do Estado moderno, observou-se que sempre há atores que buscam se beneficiar das ações do Estado, ou este atua literalmente em prol do fortalecimento de tais atores, contudo não há como tais ações não afetarem diretamente a produção do espaço, assim como os demais atores hegemonizados que ficam alheios a tais decisões, podemos ratificar isso, através de Castro (2009), ao tratar dos interesses dos atores que o Estado incorporou a partir do século XIX:

\begin{abstract}
É inegável que as decisões desse universo afetam a organização do espaço e o cotidiano dos seus habitantes mesmo que a partir do final do século XX o poder regulador das instituições politicas localizadas no aparato estatal tenha que se incorporar os interesses a outras instituições supranacionais, como o FMI, a OMC, o Banco Mundial e o mercado financeiro. Da mesma forma, no século XIX os Estados incorporam os interesses da burguesia industrial e, no século XX, incorporam os interesses dos trabalhadores na constituição do Estado do Bem-Estar (CASTRO, 2009, p. 78).
\end{abstract}

Isso nos exige ainda, que façamos um esforço ao pensar o território para além do conceito cunhado por Ratzel, vinculado estritamente ao poder e atuação do Estado. É preciso doravante, considerá-lo a partir de seus objetos e suas ações, a história dos movimentos, movimentos da sociedade, é preciso pensá-lo a partir de sua apropriação e de seu uso, é necessário pensá-lo enquanto "sinônimo de espaço humano, espaço habitado" (SANTOS, 2012, p.138). Daí, conforme já destacamos no inicio deste trabalho a escolha pela noção "uso do território" de Santos e Silveira (2008), que nos remete a entender "o espaço geográfico como sinônimo também de espaço banal', nos estimulando a pensar o espaço enquanto um direito de todos, um espaço de todos os homens, de todas as instituições, de todas as empresas (SANTOS, 2012b).

Refletir sobre o papel do Estado neste âmbito, e no período histórico atual, é reconhecer que estamos diante de um novo comportamento do Estado, movido, sobretudo pela necessidade de expansão do modo de produção capitalista, que necessita sempre de novos espaços para consolidar-se. Mediante o exposto, convém ressaltar Harvey (2013, p. 79), o qual nos lembra, que (...) "a formação do Estado em associação com o

Revista Brasileira de Ecoturismo, São Paulo, v.10, n.3, ago-out 2017, pp. 579-611. 
surgimento da constitucionalidade burguesa tem sido, por conseguinte caraterísticas cruciais da longa geografia histórica do capitalismo".

Portanto, o período histórico atual, movido pela égide da globalização, o qual submete os Estados a desafios de inserção e superação das vicissitudes do mercado mundial, sendo o ditador das regras o sistema financeiro internacional, modifica consideravelmente o papel do Estado, o qual passa a funcionar em consonância com as políticas empresarias (SANTOS, 1998).

Conquanto, aponta Harvey (2013, p. 79), "os capitalistas não requererem absolutamente esse arcabouço para funcionar, mas na ausência dele encontram maiores riscos". Até porque, é por meio das ações Estatais que a atividade capitalista poderá encontrar as melhores condições para poder se instalar e se desenvolver em determinada porção do território. Sendo assim, revela Harvey (2013, p. 111):

[...] O Estado constitui a entidade política, o corpo político, mais capaz de orquestrar arranjos institucionais e manipular as forças moleculares de acumulação do capital para preservar o padrão de assimetrias nas trocas mais vantajoso para os interesses capitalistas dominantes que trabalham nesse âmbito.

A partir da década de 1980, assiste-se a uma considerável politica de desestatização, a chamada era das privatizações, na qual as empresas públicas passaram a pertencer às iniciativas privadas, e até mesmo corporações internacionais; nutre-se o mercado internacional por meio de prerrogativas que lhes possibilitam cada vez mais a sua expansão, por meio de políticas estatais. Paralelo a isto, assiste-se, cada vez menos o Estado preocupado com a elaboração e implementação de políticas sociais, pois 0 recurso público passa a ser utilizado intensivamente para melhorias e ampliação de infraestruturas que possam servir ao capital, dotando o território (porções do território) de sistemas de engenharia, tornando-o assim mais fluído, contudo cada vez mais corporativo e fragmentado, estabelecendo, doravante um uso diferencial do território.

Esse uso diferencial do território se realiza, conforme Santos e Silveira (2008), na disputa pelos lugares luminosos e lugares opacos entre empresas com diferentes graus de modernidade capitalista ou organizacional. Nessa disputa, as empresas mais hegemônicas reivindicam os lugares mais luminosos, em virtude principalmente de sua densidade técnica que dará melhores condições às atividades econômicas que serão desenvolvidas, além é claro, do lugar, onde encontrarão a mais-valia desejada, para que se obtenha mais lucro.

Apesar do papel de grande intermediário, entre o modo de produção em escala internacional e a sociedade nacional, não se pode considerar 0 Estado como um intermediário passivo (SANTOS, 2012c), pois, 
[...] ao acolher os feixes de influencias, ele os deforma, modificando sua importância, sua direção e, mesmo sua natureza. Isto significa que a reorganização de um subespaço sob a influência de forças externas depende sempre do papel que o Estado exerce (SANTOS, 2012c, p. 226).

Portanto, é necessário refletir em até que medida pode-se falar em Estado mínimo, em falência do Estado, em morte do Estado no período histórico atual. Tanto Harvey (2005; 2013) como Santos (2009; 2012a; $2012 \mathrm{~b}$; 2012c) nos mostram o papel marcante e decisivo do Estado na (re) produção do espaço, no fortalecimento do modo de produção vigente. Talvez se encontre aí um ponto elementar em nossa discussão, e nos convoque a refletir e a questionar, Estado mínimo, morte, falência do Estado em quê e para quem?

Presencia-se a cada dia deste período hodierno, que as ações do Estado voltam-se fundamentalmente a produção do espaço para atender conforme já enfatizamos, aos interesses de uma lógica global, portanto, se por um lado as ações do Estado se dão de forma efetiva por outro lado, no que tange principalmente às suas funções sociais e políticas, observa-se um encolhimento de suas ações conforme menciona Santos (2009c).

Vale nesse sentido, considerar as ideias de Todesco (2010) ao tratar sobre o papel do Estado na organização do espaço para o turismo no Vale do Ribeira, classificando sua atuação da seguinte forma: "Presença ausente do Estado" e "Ausência presente do Estado", classificação esta que sinaliza bem a atuação do Estado no período histórico atual. O primeiro corresponde a presença do Estado em dada fração do território, através de planos, programas e projetos dentre outras ações, contudo ineficientes para proporcionar um resultado efetivo frente a demanda almejada. $O$ segundo refere-se à modificação da atuação do Estado em dada fração do território, no qual passa a não mais implementar ações diretas sobre tal, porém passa a delegá-las a outros sujeitos, como no caso o terceiro setor, este que em diversos momentos será financiado pelo próprio Estado. É assim que o Estado vai se configurando como mínimo em território nacional, num primeiro momento mostrando sua ineficiência quanto a execução de suas ações, tornando se presente, mas ausente, e por outro, delegando e financiando ações de outras instituições não públicas, como no caso instituições pertencentes ao terceiro setor, para realizar suas funções, mostrando-se ausente mas presente. É assim que vai se configurando as (in) ações do Estado no território nacional, principalmente o que se refere às questões sociais.

Restringindo suas funções politicas e sociais, o Estado amplia consideravelmente suas funções para o Mercado, mostrando políticas cada vez mais eficientes ao beneficio deste, principalmente no que se refere à instalação ou requalificação de fixos e fluxos que darão suporte a sua ampliação e fortalecimento. Contudo, nem todo território interessa ao capital, em se tratando do Brasil, observa-se como o território é descontinuo em

Revista Brasileira de Ecoturismo, São Paulo, v.10, n.3, ago-out 2017, pp. 579-611. 
termos de densidade de objetos e ações. E isso é algo histórico, que configura continuamente um agravo das diferenças territoriais, onde tais diferenças são assinaladas principalmente pelo uso do território pelo mercado e pelo Estado, os quais, num jogo dialético, serão determinantes para o uso de uma dada porção do território em determinado período, dotando-a de valor ou não, de acordo com interesses externos ao território.

Tratando-se do período atual, em que a evolução das técnicas a partir da ciência foram fundamentais para promover uma modernização do espaço, é importante destacar que:

[...] Cada ponto do território modernizado é chamado a oferecer aptidões especificas à produção. [...] Alargam-se os contextos ao mesmo tempo em que as regiões perdem o comando sobre o que nelas acontece, contribuindo para uma verdadeira fragmentação territorial. As novas vocações regionais são amiúde produtoras de alienação, pela pressão da ordem global sobre as populações locais (SANTOS e SILVEIRA, 2008, p. 106).

Diante disso, assim como porções do território são valorizadas num dado período histórico, por uma determinada atividade econômica, elas poderão deixar de vir a ser em outro. Sua valorização e/ou desvalorização dar-se-á de acordo com as leis do mercado, mas não nacional, e sim mundial, que ao impor uma lógica externa, desencadeia implicações territoriais e sociais, que se sobrepõem a lógica do lugar.

É desta forma que o turismo, enquanto atividade econômica foi sendo incorporado ao território brasileiro; se considerarmos a sua ocorrência de forma efetiva, podemos considerar apenas frações do território, já que tanto - Estado quanto o Mercado selecionam apenas frações do território brasileiro para o investimento em tal setor.

Diante disso, criou-se uma racionalidade para o desenvolvimento do turismo no Brasil, em que prevalece o imperativo do Mercado, principalmente quando se estimula a construção de destinos turísticos como simulacros, visando simplesmente atender um mercado consumidor, desvirtuando o cotidiano e transformando a imagem do lugar.

\section{Terceiro Setor}

O termo terceiro setor é proveniente dos Estados Unidos, traduzido da expressão em inglês Third Sector e que no Brasil ganhou novos contornos, principalmente a partir da democratização do Estado brasileiro no final da década de 80 do século $\mathrm{XX}$, e que faz emergir um novo ator no cenário nacional, e que se consolidada na década de 90 do mesmo século como principal mecanismo de alcance de políticas públicas sociais pela população pobre brasileira.

Desta forma já se pode identificar que o Terceiro Setor apesar de incorporar algumas caraterísticas do Primeiro Setor (Estado) e do Segundo 
Setor (Mercado), não corresponde a nenhum dos dois setores, por mais que as atividades desenvolvidas por este caracterizem-se como privadas, os seus objetivos são públicos. De acordo com Monte (2002, p. 70), "tal hibridização permite a defesa da existência de uma esfera pública não estatal, cuja importância está na capacidade de gerar dividendos sociais".

O Terceiro Setor no Brasil surgiu, segundo Monte (2002), por volta da década de 70 e 80 do século XX, motivado pela necessidade de defesa dos direitos sociais no período da ditadura militar, e sua expansão e consolidação no território brasileiro correram em decorrência de vários fatores, dentre os quais destaca:

a inoperância da maquina estatal em promover condições mínimas de sustentabilidade social a uma classe de indivíduos excluída; o processo de globalização, que por meio do modelo capitalista de extinguiu postos de trabalho e fechou empresas e o fim do regime militar no país (MONTE, 2002, p. ).

É possível ainda identificar outras nomenclaturas relacionadas ao terceiro setor, dentre as quais destaca-se ONG - Organizações Não Governamentais, a qual popularizou-se no cenário nacional. Assim, enquanto nomenclatura para instituições que se encontram com este formato, adotaremos a terminologia ONG neste trabalho.

Segundo Landim (2002), a nomenclatura ONG foi utilizada pela $1^{\circ}$ vez em 1940, pelas Nações Unidas - ONU. Era um termo que com frequência aparecia em seus documentos para designar "um universo bastante amplo e vago de organizações com as quais a ONU poderia estabelecer consultorias".

Inicialmente, ONGs correspondiam, no Brasil, principalmente às organizações de cooperação internacional (COUTINHO 2004), formadas geralmente pelas Igrejas católicas e protestantes, organizações de solidariedade, ou governo de vários países, as quais direcionavam suas ações a organizações e movimentos sociais, visando a democratização do país.

As ONGs de defesa de direitos, criadas nas décadas de 1970 e 1980, em geral, desenvolviam um trabalho na base da sociedade, que visava a democratização e a ampliação de direitos no país, em oposição a um Estado militar autoritário e violador de direitos. O formato associativo foi a expressão institucional encontrada para contribuir na construção de um Estado democrático de direitos e de uma sociedade multicultural, livre de seculares estruturas de poder, dominação e desigualdade (ABONG, p. 13)

Com a democratização do país no final da década de 1980, e com a instalação de uma economia neoliberal no Brasil a partir de 1990, há uma consolidação deste setor no país. No entanto, passam a atuar com uma 
lógica, com ações políticas diferentes das dos anos de 1970 e 80 . Se naquele período suas ações estavam relacionadas essencialmente aos movimentos sociais, em uma luta contra o Estado, doravante, as ONGs passam a buscar parcerias com o próprio Estado, uma vez que como ressaltado em nossa discussão anterior sobre este, a partir da década de 90 do século XX, torna-se ineficiente na elaboração e na execução das políticas sociais do país. Além do Estado, tais organizações passam também a estreitar relações com as empresas privadas. É desta forma, que vão se estruturando no cenário nacional e firmam-se como instituições cidadãs e sem fins lucrativos.

De acordo com Coutinho (2001, p. 58), as ONGs iniciam a partir da década de 90 uma nova trajetória, com um novo perfil, o qual se configura como um "perfil de filantropia empresarial", passando a manter relações estreitas com o Banco Mundial e com as agências financiadoras ligadas ao grande capital, com o caso das fundações Ford, Rockfeller, Kellog, Mac Arthur, entre outros.

Se na década de 1970 os objetivos destas baseavam-se na politização dos movimentos sociais, em 1990 os objetivos passam a incorporar lemas como desenvolvimento autossustentável (COUTINHO, 2001).

A década de 1990 foi, de acordo com Coutinho (2001), fundamental para a popularização do termo ONG, bem como para sua consolidação no cenário Nacional. Contudo, a autora diz que houve uma divisão de tais instituições, as quais se identificam, ou melhor, se imaginam num campo progressista, e há aquelas ONGs que colaboram com a política neoliberal, desta forma pode-se dizer que acompanhado da reestruturação do Estado, veio também uma ruptura dos objetivos unos das ONGs no Brasil: algumas ainda permaneceram com o ideário de desenvolver ações que incitam a busca pelos direitos sociais e políticos, e outras não, que seguiram as regras impostas pela economia neoliberal.

Petras (1999) e Coutinho (2001) apontam que a década de 1990 foi um período que ocorreu um enfraquecimento dos movimentos sociais, bem como da própria sociedade organizada pelas conquistas de políticas sociais, apontando que as ações de certas ONGs a partir deste período destoam do compromisso político e social reivindicado pela população brasileira, bem como utilizado como discurso da maioria destas.

O impacto substantivo de suas ações converge para desviar "o povo da luta de classes para formas inofensivas e ineficientes de colaboração com os seus opressores" (1999:41). Elas despolitizam e desmobilizam os pobres com suas ações focadas na "auto-ajuda". Debruçam sobre temas como "excluídos", "discriminação racial", "relações de gênero" sem ir além do sintoma superficial, para engajar o sistema social que produz essas condições. Incorporando os pobres à economia neoliberal através da simples "ação voluntária privada", as ONGs geram um mundo político onde a aparência da solidariedade e da ação social disfarça a 
conformidade conservadora com a estrutura de poder internacional e nacional (PETRAS, 1999).

Diante disso, é preciso traçar uma reflexão do real papel desse setor, uma vez que este, como menciona Neder (1998), não é governo, nem mercado, mas sim uma esfera pública não estatal e não mercantil, ocupada com a superação da exclusão social. Porém, é uma reflexão que exige um grande esforço de análise, principalmente quando nos deparamos com a diversidade de ONGs, com os mais distintos objetivos, que revelam por si só, "um universo bastante complexo, diverso, dinâmico e desigual, e instituirse como não governamental não garante uma concepção pronta nem encerrada" (ABONG, 2010).

\section{A ONG "Projeto Saúde \& Alegria" e sua Atuação no Oeste do Estado do Pará}

O Centro de Estudos Avançados de Promoção Social e Ambiental CEAPS, conhecido popularmente como "Projeto Saúde e Alegria", é uma entidade civil, sem fins lucrativos, fundada no ano de 1985, no município de Santarém, oeste do Estado do Pará. Em maio de 2001 foi reconhecida como Entidade de Utilidade Pública Municipal, através da Lei № 16.902/2001 Santarém/PA, e em março de 2006, reconhecida como Entidade de Utilidade Publica Federal, por meio da Portaria 266 do Ministério da Justiça publicada no Diário Oficial da União. Além disso, é registrada desde o ano de 1998 no Conselho Nacional de Assistência Social - Brasília/Distrito Federal, através da Resolução no 174, e foi certificada em maio de 2007 como Entidade Beneficente de Assistência Social - Resolução no 71 publicada no Diário Oficial da União (ONG PROJETO SAÚDE \& ALEGRIA, 2009).

É importante destacar que antes da criação da ONG, no ano de 1983, os seus fundadores, os empreendedores sociais Eugênio Scannavino Netto (médico sanitarista) e Márcia Silveira Gama (arte educadora), foram contratados pela Prefeitura de Santarém para prestar assistência na área da saúde em comunidades ribeirinhas do município. A partir de então, começaram a desenvolver ações que pudessem contribuir, sobretudo na melhoria da saúde dessas populações, diante disso, além do atendimento médico prestado, implementaram ações de prevenção, pesquisa, treinamento com voluntários locais, e gincanas educativas, visando justamente minimizar problemas que afetavam a grande maioria dessas populações, e que ampliavam o número de mortalidade infantil na região (ONG PROJETO SAÚDE \& ALEGRIA, 2014).

No entanto, com o fim do contrato com a prefeitura de Santarém no final de 1984, em decorrência do encerramento do mandato do Gestor municipal do então período, as atividades realizadas por tais empreendedores sociais tiveram que ser interrompidas. Daí a grande motivação para a criação da ONG, que permitiria dar continuidade às atividades em tais comunidades de forma independente da prefeitura. Nesse processo inicial, dois colaboradores foram fundamentais para firmar a

Revista Brasileira de Ecoturismo, São Paulo, v.10, n.3, ago-out 2017, pp. 579-611. 
proposta do projeto da ONG, o sanitarista Sérgio Arouca vinculado à Fundação Oswaldo Cruz, e Cesare Della Rocca, representante nesse período no Brasil da Unicef - Fundo das Nações Unidas para a Infância, que além de colaborarem para a manutenção das atividades, foram em busca de financiamento para consolidar as atividades da ONG.

Sendo assim, apesar de sua criação no ano de 1985, suas atividades iniciaram de fato somente no ano de 1987, estas direcionadas inicialmente a 16 comunidades-piloto, todas pertencentes à área rural do município de Santarém. Isso só fora possível com a conquista de seu primeiro convênio de cooperação, estabelecido entre BNDES - Banco de Desenvolvimento Econômico e Social (concessor de recursos), UFPA - Universidade Federal do Pará (Interventora), e a Fundação Oswaldo Cruz (Supervisão técnica).

A sua área de atuação foi ampliada a partir do ano 2000 e que além de comunidades da área rural de Santarém, foram envolvidas comunidades de municípios vizinhos, como Belterra, Aveiro e recentemente Juruti, desenvolvendo ações principalmente com populações tradicionais, no sentido de emponderá-los e Ihes auxiliar "na defesa de suas terras, de seus recursos naturais e na viabilidade social, econômica e ambiental de seus territórios" (ONG PROJETO SAÚDE \& ALEGRIA, 2014).

As comunidades que são contempladas com as ações da ONG são geralmente localizadas em áreas rurais dos municípios e a distância entre a sede municipal e tais comunidades é, sem dúvida, um dos principais desafios que as mesmas enfrentam, uma vez que há uma rarefação de infraestruturas, que limitam o acesso de tais comunidades à cidade bem como se torna uma justificativa para a precariedade dos serviços prestados pelo poder público municipal e estadual no local, já que em sua maioria são interligadas as sedes municipais por meio de rios e estradas não pavimentadas. É nesse contexto que a ONG PSA passou a desenvolver suas atividades nessa fração do território, agindo como uma intermediária entre entidades públicas e privadas e tais populações.

Assim, a ONG PSA tornou-se um elo entre as populações envolvidas e o acesso a tais serviços, bem como às políticas públicas de um modo geral, já que estas, no caso mais específico do município de Santarém, historicamente, enfrentam o descaso do poder público local, estadual e federal bem como a intensa burocracia nos órgãos públicos para ter acesso a tais serviços.

É para este público que a ONG, baseada em uma metodologia participativa, busca desenvolver ações, as quais não se restringem à área da saúde, mas abrangem uma diversidade de temáticas, que vislumbram a melhoria da qualidade de vida dessas populações envolvidas. Desta forma a partir da elaboração de um planejamento estratégico no ano de 2009, o qual corresponderia de 2010 a 2015, suas ações desenvolveram-se dentro de 4 (quatro) grandes eixos temáticos, conforme observado a seguir (Figura 1): 


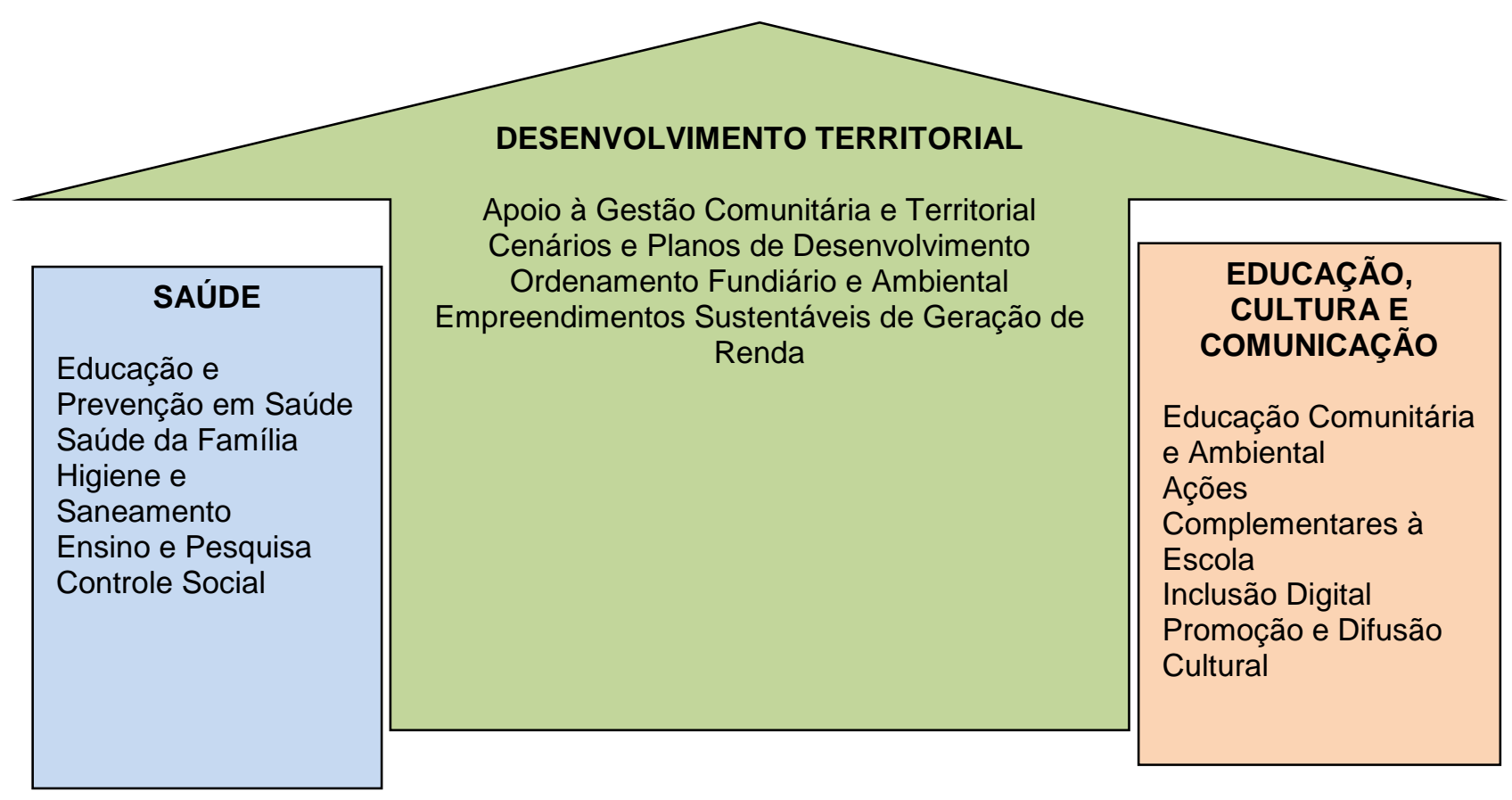

\section{INTEGRAÇÃO INSTITUCIONAL}

Articulações e Políticas Institucionais

Disseminação, Expansão e Replicação

Sustentabilidade

Figura 1: Programas Desenvolvidos pela ONG Projeto Saúde e Alegria.

Figure 1: Programs developed by the NGO Projeto Saúde e Alegria.

Fonte: organizado por Elcivânia Barreto, com base no modelo apresentado no Plano

Estratégico 2010-2015 da ONG PSA.

Source: organized by Elcivânia Barreto, based on the model presented.

Além de ampliar suas escala de atuação, a ONG PSA maximizou suas ações, dando continuidade aos projetos já existentes e desenvolvendo novos, os quais corresponderam a: Saúde Fluvial, Saneamento Básico, Mapeamento Participativo, Inclusão digital, Ações Complementares à Escola, Artesanatos da Floresta, Ecoturismo de Base Comunitária.

\section{O Turismo de Base Comunitária na Comunidade Ribeirinha de Anã}

A trajetória do Turismo de Base Comunitária em Anã se dá mediante a firmação da atuação da própria ONG PSA na comunidade, pois, este é parte de um amplo projeto criado e coordenado pela ONG PSA. Portanto, não se pode prescindir a trajetória do TBC em Anã, da presença e atuação da ONG PSA na comunidade.

No ano de $2001^{5}$, a ONG PSA organizou em parceria com o Projeto Bagagem $^{6}$, uma expedição pelas comunidades ribeirinhas de Santarém, 0 qual se denominou Roteiro Amazônia Ribeirinha, esta que também deu origem a ONG Projeto Bagagem. A partir desta primeira expedição, além da estruturação do projeto Bagagem como ONG, passou-se a organizar 2 
(duas) expedições anuais, esta que consistia em levar pequenos grupos de turistas (entre 10 e 15 pessoas) a conhecerem uma fração do território santareno, mais precisamente o território de comunidades ribeirinhas do município.

Esta experiência com o projeto Bagagem foi o marco inicial para 0 desenvolvimento de outros roteiros pela ONG PSA, não somente com o Projeto Bagagem, mas com outros parceiros, outras instituições, como World Learning Brazil, Ambiental Expedições, I-To-I /lkoPoram. Além destas viagens, a ONG PSA ainda tem organizado viagens demandadas pelos seus parceiros financiadores, com a finalidade de levá-los a conhecer os projetos desenvolvidos pela ONG nas comunidades.

Foi mediante tais experiências desenvolvidas pelo PSA que o mesmo, a fim de fomentar e consolidar o turismo como uma alternativa de renda nas comunidades ribeirinhas do município de Santarém, elaborou, no ano de 2008, um projeto intitulado "Ecoturismo de Base Comunitária no Polo Tapajós", o qual fora submetido ao Ministério de Turismo para concorrer a obtenção de financiamento disposto através do Edital n0001/2008 do MTur. Como já ressaltado anteriormente, esta foi a primeira vez em que o Estado contemplou em suas políticas de turismo, ações para esta modalidade de turismo; pela primeira vez, o chamado turismo de base comunitária ganhou visibilidade nas políticas do Estado.

É nesse contexto que a comunidade ribeirinha de Anã envolveu-se com o projeto de turismo de base comunitária desenvolvido pela ONG PSA. Como citado anteriormente, este projeto contemplou quatro comunidades ribeirinhas do município de Santarém, dentre as quais Anã. A seleção das comunidades para participação no projeto foi feita pela ONG PSA. Contudo, era uma escolha que dependia principalmente do próprio interesse das comunidades em participar, e este foi um dos pontos avaliados pela ONG no momento em que esta levava a proposta às comunidades.

Como Anã já havia demandado este tipo de projeto, alguns comunitários já possuíam curso de "condutor de turismo", o qual fora ofertado pelo SENAR - Serviço Nacional de Aprendizagem Rural, para várias comunidades ribeirinhas de Santarém, o que de certa forma contribuiu para a inserção de Anã no projeto de turismo de base comunitária elaborado pela ONG PSA, contudo, foi principalmente o interesse dos comunitários, que levou a comunidade a ser selecionada para fazer parte do projeto de TBC.

Convém mencionar que antes do projeto de ecoturismo de base comunitária, a ONG PSA atuava na comunidade, com ações inseridas no seu programa de Saúde, estas relacionadas aos atendimentos realizados por uma equipe de médicos através do Barco Abaré, e com o projeto de implantação dos microssistemas de abastecimento de água, o qual, Anã fora contemplada no ano de 2005, com a instalação de um microssistema, este último que trouxe grandes melhorias para a comunidade, uma vez que havia uma grande incidência de casos de vômito e diarreia, principalmente entre as crianças e os idosos da comunidade. 
A inserção de Anã no projeto de ecoturismo de base comunitária desenvolvido pela ONG PSA foi fundamental para a organização da prática na comunidade, e apesar da hesitação de alguns comunitários em relação ao pertinente projeto, os comunitários entrevistados, não somente os envolvidos, mas os não envolvidos com o projeto, apontam que a ONG PSA foi importante para a comunidade, principalmente pelos projetos que a mesma tem desenvolvido na comunidade, os quais, como vimos anteriormente, não se restringem apenas ao de ecoturismo.

Após a formalização de Anã no projeto de turismo da ONG PSA e com a seleção do projeto pelo Ministério do Turismo, através do Edital n-001/2008 para financiamento, iniciaram-se as oficinas de qualificações das comunidades, que como já citamos, além de Anã, haviam mais três comunidades envolvidas no projeto.

Em seguida, os comunitários envolvidos nas oficinas foram levados à construção de um inventário, cada grupo das comunidades deveria identificar os atrativos existentes em suas comunidades, como os projetos que as mesmas desenvolviam, além de elementos de sua configuração territorial que consideravam interessantes, e que pudessem ser apresentados aos visitantes.

Ao final do inventário de cada comunidade, apresentou-se ainda um "diagnóstico preliminar de ecoturismo", o qual correspondia a possíveis atividades que os visitantes poderiam realizar nas comunidades, assim como as possibilidades e limitações de cada comunidade para o desenvolvimento do projeto.

Tratando-se mais especificamente de Anã, o diagnóstico apontou de forma preliminar, que os atrativos turísticos potenciais na comunidade, seriam: Trilhas, Lago do Anã e suas cabeceiras, praias, casa de farinha, igarapés, projetos (melipomel, MUSA, APRONÃ), artesanato, cultura da comunidade, modo de vida dos comunitários, piracaias (Expressão utilizada no Pará para designar "peixe assado na praia").

Quanto às limitações encontradas na comunidade para o desenvolvimento do projeto, identificaram a inexistência de um local de recepção dos visitantes, falta de uma hospedagem, refeitório, além de alguns cursos, como de culinária, inglês, primeiros socorros, e oficina de reciclagem.

Concluiu-se o diagnóstico, apresentando o grupo de comunitários que comporiam a comissão de ecoturismo de Anã, formada inicialmente por 5 (cinco) comunitários, que fizeram, no período de outubro a dezembro de 2008, o Curso de Capacitação básica de condutores ambientais locais, realizado pelo programa de apoio ao Ecoturismo e à sustentabilidade ambiental do turismo do Ministério do Meio Ambiente, com apoio do ICMBIO.

Após a primeira fase de qualificações e ao passar pelo primeiro teste ao receber o grupo de estudantes norte-americanos, percebeu-se que Anã encontrava-se preparada para a recepção de outros visitantes. Assim

Revista Brasileira de Ecoturismo, São Paulo, v.10, n.3, ago-out 2017, pp. 579-611. 
iniciou-se uma nova fase em que Anã, assim como as outras comunidades envolvidas no projeto, começaram a receber visitantes.

A ONG PSA passou a executar o roteiro proposto apresentado em seu projeto, o qual correspondia à visitação nas 4 (quatro) comunidades participantes no projeto, as quais foram: Anã, Atodí, Arimum e Vila Amazonas. O Roteiro tinha a duração de 5 (cinco) dias, geralmente o tempo em cada comunidade correspondia a um (1) dia, no qual percorriam os projetos, realizavam refeições, compartilhavam experiências com os visitantes através das rodas de conversas, momento este em que os visitantes e os comunitários trocavam conhecimentos.

Após um período realizando este tipo de roteiro, em suas avaliações, a ONG juntamente com as comunidades, começaram a perceber a necessidade de encontrar outra forma de levar visitantes as comunidades, a qual possibilitasse a ampliação de benefícios às comunidades, uma vez que o tipo de pacote oferecido às pessoas, ao utilizar o barco para percorrer as 4 (quatro) comunidades durante 5 (cinco) dias, encarecia o custo da viagem, deixando uma renda baixa para a comunidade, tendo em vista o custo alto com a locação da embarcação, compra de diesel, tripulação do barco (comandante, marinheiro, cozinheiro) além de mediadores culturais da ONG PSA, impedindo desta forma, conforme assinalou o coordenador do projeto, uma transferência maior de renda à comunidade.

Outra limitação desta forma de roteiro, apontada pelo coordenador do projeto, era o fato de existir uma grande demanda para visitar as comunidades, porém parte desta demanda não se interessava por este tipo de viagem, ou melhor, ter que passar 5 (cinco) dias viajando em um barco, convivendo com outras pessoas, afinal o grupo recebia pessoas de diferentes estados, regiões do país, pessoas até então desconhecidas uma das outras. O fato é, que nem todas as pessoas que procuravam pelo ONG na busca do roteiro turístico pelas comunidades, estavam dispostas a este tipo de convivência, com pessoas desconhecidas, assim como com a experiência em ter que dormir durante 5 (cinco) dias em um barco, bem como em redes.

Outro ponto retomado como limitação, foi a falta de infraestrutura adequada e necessária para atender os visitantes, uma vez que o barco utilizado no transporte servia como infraestrutura de apoio para as refeições, higiene pessoal dos visitantes dentre outras coisas, conforme apontou 0 coordenador do projeto de EBC da ONG PSA.

Foi levando em consideração tais limitações que a ONG PSA, juntamente com as comunidades, mais especificamente Anã, começaram a pensar na possibilidade de criar uma pequena infraestrutura que viesse atender essas pequenas necessidades. No ano de 2009, deu-se início, ao processo de discussão sobre a construção de uma pousada comunitária, que além de possuir uma área que serviria como dormitório, teria uma área para cozinha, e banheiros. Apresentou-se assim um projeto de uma hospedaria, tanto para Anã, quanto para a outra comunidade, Atodí, comunidades que atualmente ${ }^{7}$ apresentam estruturas de hospedagem em 
seu território. Em Anã, a pousada recebeu o nome de "Hospedaria Comunitária de Anã", portanto adotaremos o termo hospedaria.

No ano de 2010, a ideia da construção da hospedaria ganhou corpo, através da formulação de um documento, o qual fora apresentado a um dos parceiros da ONG PSA, o Núcleo Oikos ${ }^{8}$, que aprovou a ideia do projeto e de imediato se propôs a concretizá-lo. A forma inicial de ajuda concedida pelo Núcleo Oikos ocorreu ainda em 2010, ao apresentarem um arquiteto que elaborou um desenho preliminar da hospedaria, e que juntamente com os comunitários envolvidos, e a ONG PSA, encontraram uma área na comunidade, onde a mesma seria construída a hospedaria. Com a elaboração do desenho, da hospedaria e a escolha da área para a construção, organizou-se um projeto que fora encaminhado para o ICMBIO, para que o mesmo avaliasse e autorizasse a obra, uma vez que a construção da hospedaria dar-se-ia em uma área localizada em uma unidade de conservação.

Após esta fase, consolidada com a autorização concedida pelo ICMBIO, elaborou-se um orçamento do custo do projeto, o qual fora dividido em etapas, e a partir disso, iniciou-se o processo de captação de recursos para a execução do projeto.

Conseguiram por intermédio de doações uma arrecadação de $R \$$ 20.000,00 , (Vinte Mil reais), para dar início à construção da hospedaria. Como se tratava de uma quantia pequena, a dúvida era o que se começaria a construir primeiro, já que tudo era necessário, banheiros, cozinha e o redário . No ano final de 2012, um dos parceiros da ONG PSA, a cooperação Alemã, estava com um recurso disponível em caixa e o mesmo seria devolvido, foi então que a ONG PSA apresentou o projeto da construção da pousada comunitária, e conseguiu obter um valor de $R \$ 84.000,00$ (Oitenta e quatro mil reais), o qual somou-se ao valor de $R \$ 20.000 .00$, que foram fundamentais para a fase inicial construção da pousada. Porém, outras doações foram feitas, como já ressaltado, por pessoas físicas e jurídicas, as quais acreditaram na proposta do projeto.

Logo após a finalização da construção do redário e dos banheiros, iniciou a outra fase do projeto, a construção da cozinha e do refeitório, pois no final do ano de 2013 conseguiram recursos de outro órgão financiador. Até setembro de 2014, foi arrecadado e empregado na construção da hospedaria um valor de $\mathrm{R} \$ 160.000,00$ (Cento de sessenta mil reais).

Até o período da pesquisa de campo, os comunitários envolvidos com o projeto de TBC e a ONG PSA esgtavam trabalhando em busca de recursos para a compra de placas solares, uma vez que não há energia elétrica na comunidade, e a melhor alternativa para a geração de energia na pousada seria através das placas solares, utilizando assim a energia solar.

Como se pode perceber, a atuação da ONG PSA em Anã se consolidou com o projeto de ecoturismo de base comunitária que a mesma desenvolve na comunidade desde o ano de 2008. Apesar de sua atuação anterior, com projetos ligados ao seu programa de Saúde, a implementação do projeto de EBC em Anã configurou uma nova relação entre a ONG e a 
Comunidade. Atualmente, a atuação da ONG na comunidade não se restringe apenas ao projeto de EBC; paralelo a este projeto, há outros projetos em desenvolvimento, como o caso do projeto do viveiro.

É necessário ressaltar que quando se fala em comunidade de Anã, partimos da referência do território de Anã, porém nem toda a comunidade é envolvida ativamente no projeto. Até setembro de 2014, das 96 famílias existentes em Anã, participavam de forma direta e indireta aproximadamente 30 famílias, dentre as quais, aquelas participando de forma direta na recepção dos visitantes, realização das refeições, e aqueles que participam vendendo seus produtos para atender a demanda de visitantes, principalmente no que se refere aos produtos utilizados no preparo das refeições aos visitantes, como a galinha caipira, o peixe, hortaliças, frutas para o preparo do suco.

Em relação ao papel do Estado frente ao tbc em Anã, não podemos considera-lo ausente, uma vez que foram identificadas ações concretas do poder municipal e federal na comunidade, contudo em áreas como educação e saúde e habitação, em relação ao turismo, podemos considerar o Estado em todas as esferas praticamente ausente, uma vez que foram desenvolvidas ações pontuais em Anã, e com mais destaque a atuação do Governo Federal, conforme já mencionado, através do recurso advindo do Ministério do Turismo em 2008 em decorrência do Edital de Chamada Pública de Projetos MTur/№ 001/2008

Identificamos que entre 2008 até 2014, não houve qualquer forma de ação por parte do Estado, no que se refere às esferas municipal e estadual. No que tange à atuação do Estado a nível federal, identificamos apenas o edital no 001/2008 do Ministério do Turismo, que direcionou uma verba de $147.766,50$ (cento e quarenta e sete mil e setecentos e sessenta e seis reais e cinquenta centavos) ao projeto de ecoturismo de base comunitária que fora submetido pela ONG PSA, contemplando além de Anã, três comunidades envolvidas no projeto.

De acordo com o coordenador do projeto de turismo de base comunitária desenvolvido em Anã, além do recurso advindo do Ministério do Turismo, não houve qualquer outra forma de manifestação do Estado para com o projeto de Turismo de Base Comunitária, seja em Anã ou em outras comunidades. A ONG procurou algumas vezes articular e solicitar algumas ações por parte dessa entidade, porém não foram exitosas, até pelo fato da falta de objetividade do Estado em suas ações, bem como da urgência em realizar e consolidar 0 projeto de TBC nas comunidades, mais especificamente em Anã, principalmente no período de construção da hospedaria, que houve uma maior necessidade de captação de recursos. Porém não descarta a possibilidade de parcerias com este.

Diante do exposto, podemos considerar que no que se refere à atuação do Estado, através do poder público municipal de Santarém, desde o período em que se iniciou o projeto em 2008, até o ano de 2014, não houve ações efetivas e direcionadas à comunidade ribeirinha de Anã, no que tange ao TBC desenvolvido sob a coordenação da ONG PSA. 
Pelo que podemos identificar no exposto, tanto os ex-secretários como a secretária que estava à frente da secretaria de turismo durante 0 período, reconhecem a importância do projeto que a ONG tem desenvolvido, assim como apontam a relevância da ONG nessas comunidades, principalmente quando observam a efetivação dos projetos nas comunidades ribeirinhas.

Como não foram solicitadas ações por parte da ONG, assim como pela comunidade Anã à secretaria de turismo, esta também não manifestou interesse em colaborar com ações efetivas ao projeto implementado em Anã. A ONG apresenta um grau de independência, principalmente no que se refere aos projetos e sua atuação nas comunidades ribeirinhas, que leva de certa forma à atenuação da atuação do poder público em tais comunidades, principalmente no que se refere à comunidade de Anã, nosso local de estudo. A atuação do poder público se dá, como ressaltado, na prestação de serviços básicos, como saúde, educação e habitação.

\section{Considerações Finais}

A discussão sobre a Amazônia nos remete geralmente a imagem, ou melhor atrela sua imagem a recursos naturais, biodiversidade, o grande potencial desta para implementar alternativas sustentáveis de desenvolvimento, ou como esta representa um grande laboratório científico a céu aberto, e quase sempre esquecemos do fator humano, fator populacional que compõe esta fração do território brasileiro.

Anã, comunidade ribeirinha da Amazônia reflete justamente esta imagem que devemos desconstruir. Atualmente, Anã tem se estacado como uma das comunidades da RESEX que mais tem empreendido projetos, ressaltando a eficácia destes para a comunidade. Dentre tais projetos, destacamos neste trabalho o projeto de TBC, o qual tem sido desenvolvido em parceria com a ONG PSA desde o ano de 2008, período este que marca o inicio da forte atuação da ONG PSA junto a comunidade de Anã.

Em nossa pesquisa, partimos do entendimento do turismo de base comunitária enquanto um contra-movimento, uma racionalidade contrahegemônica, que diante dos ditames da lógica racional do turismo convencional, busca reavivar valores, encontros entre o $\mathrm{Eu}$ e tu (Martin Bubber), e proclamar a desalienação, adormecidos no atual período técnicocientifico e informacional.

Diante disso, analisamos a experiência de TBC em Anã, a partir do papel do Estado, da ONG Projeto Saúde e Alegria, assim como a partir da própria atuação da comunidade.

Pelo que analisamos as decisões tomadas em relação ao TBC na comunidade, centralizam-se no grupo de turismo, assim como na ONG PSA. Sendo que esta última configura-se como principal agente hegemônico do turismo na comunidade, intermediando a ida dos grupos a comunidade, selecionando os visitantes, uma vez que aplica um questionário para identificar se a pessoa que se predispõe a conhecer não somente Anã, mas

Revista Brasileira de Ecoturismo, São Paulo, v.10, n.3, ago-out 2017, pp. 579-611. 
outras comunidades que desenvolvem o projeto de TBC tem o perfil adequado, já que como revelado, é uma viagem diferenciada.

A ONG, identificada como agente hegemônico no processo é um dos agentes responsáveis pela divisão das funções entre as pessoas que compõem o grupo de turismo, como o caso da pessoa que foi indicada para assumir a função de "anfitrião da comunidade".

Como ressaltamos, a relação da comunidade Anã com a ONG PSA estreitou-se a partir de 2008, quando a ONG lançou a proposta do projeto de TBC para a comunidade, que envolveria além desta, mais 3 (três) comunidades. Tal projeto foi submetido ao Ministério do Turismo para obtenção de recursos, o qual foi fundamental para o desenvolvimento do projeto em tais comunidades.

Com base em nossas análises, identificamos que a ONG PSA foi e é determinante para a implantação e continuidade do projeto em Anã. Apesar da invocação contínua do termo comunidade ao referir-se a experiência de TBC em Anã, das 96 famílias existentes, 30 famílias participam do projeto, porém uma parcela da renda gerada pelo projeto é destinada à Associação da Comunidade, sendo assim o projeto tem alcançado direta e indiretamente as famílias. Contudo, há comunitários que não tem conhecimento desta renda que é direcionada a associação, assim como aqueles que revelam que nunca viram o emprego do dinheiro do TBC em melhorias para a comunidade.

A participação dos comunitários no projeto de TBC se dá principalmente na cozinha da hospedaria, pois é onde se concentra uma maior demanda de tarefas a serem executadas durante a presença dos visitantes. Há dois comunitários que lideram o grupo de turismo, organizando-o para os dias em que haverá visitantes na comunidade. Tais comunitários são geralmente os quais discutem com a ONG PSA o desenvolvimento e organização do projeto de TBC, contudo mais uma vez, foi possível identificar que a ONG ainda detém maior hegemonia nas discussões em relação do projeto de TBC.

O projeto de turismo de base comunitária em Anã consolidou-se com a construção da hospedaria comunitária, tornando possível hospedar os visitantes e assim fazê-los permanecer mais de 1 (um) dia na comunidade, este que durante sua estada podem realizar visitas a outros projetos desenvolvidos pela comunidade, como o projeto de criação de peixes, 0 projeto melipomel, além do viveiro.

Vale destacar, que o visitante que chega à comunidade tem uma relação mais direta com os comunitários que são envolvidos com o projeto, mais precisamente os quais são escalados para trabalhar durante o dia de visitas, sendo assim, o visitante não mantem contato com os demais comunitários não envolvidos.

Apesar da consolidação e evidência do projeto de TBC coordenado pela ONG PSA no município de Santarém, identificamos que houve poucas manifestações do Estado em prol deste, esta manifestada principalmente e 
unicamente por ações no âmbito nacional, como a contemplação do projeto de TBC no ano de 2008 pelo edital n-001/ MTur, além da atuação do ICMBIO, que viabilizou autorizações a comunidade para a construção da hospedaria comunitária.

No que se refere às ações no âmbito estadual, constamos a inexistência de tal, assim como em seus planos, não foram identificadas ações nesse sentido, que pudessem contemplar o TBC em Anã, ou no próprio município de Santarém. Contudo, identificamos que o Governo Estadual, se faz presente na comunidade através do Sistema Modular de Ensino Médio. Constatamos ainda, no que se refere a outros programas da ONG, que este nível de Estado, foi parceiro da ONG PSA entre os anos 2012 e 2013, porém nada relacionado ao projeto de TBC.

$\mathrm{Na}$ esfera municipal, identificamos que este atua nas áreas de educação e saúde, porém o órgão responsável pelo turismo no município não havia, até setembro de 2014, realizado, nem planejado ações para o projeto de TBC em Anã, considerando a ONG avançada e organizada nessa questão, e, portanto sendo desnecessária uma ação efetiva da Secretaria, até pelo fato de serem escassos os recursos financeiros desta, inviabilizando assim uma maior atuação desta no município. Consideram ainda a autossuficiência da ONG na execução deste projeto, bem como a proteção desta em relação aos projetos que desenvolve, assim como em relação as comunidades em que é atuante, como no caso de Anã. .

Diante disso, consideramos que a ONG PSA, assume papel hegemônico na implementação de ações que conduzem ao desenvolvimento territorial das comunidades ribeirinhas contempladas com seus projetos. Constitui-se como um ator crucial para tais comunidades, realizando ações muito mais efetivas do que o próprio Estado. O Estado por outro lado, considerando a presença da ONG, mais especificamente em relação ao turismo de base comunitária, e tratando-se do Estado em âmbito municipal, considera desnecessário o direcionamento de ações para Anã, uma vez que a ONG vem desempenhando com êxito seu trabalho.

Levando em consideração a presença hegemônica da ONG PSA na organização do espaço para o turismo em Anã, não é possível neste momento apontá-la como uma contra-racionalidade hegemônica, assim como a lacunas existentes entre o grupo de comunitários que são envolvidos com o TBC e os comunitários que não são envolvidos. Ainda que, é possível identificarmos o elemento econômico sobrepondo-se a comunidade, tendo em vista a desconfiança que é gerada em decorrência do valor que é repassado do projeto de TBC à associação dos comunitários, que assim como a forma de gestão da hospedaria comunitária, tem sido a causa de descontentamentos de certos comunitários.

Destarte, não podemos desconsiderar a importância da experiência de TBC desenvolvida em Anã pela ONG PSA. A mesma nos revela as contradições existentes no processo de produção do espaço para o turismo em Anã, assim como nos aponta os conflitos que emergiram em decorrência da falta de esclarecimentos sobre o Projeto de TBC. Mas, além disso, a

Revista Brasileira de Ecoturismo, São Paulo, v.10, n.3, ago-out 2017, pp. 579-611. 
mesma nos revela uma relação de um grupo de comunitários com o território, que além de buscar alternativas através do TBC de geração de renda, busca permanecer e contribuir para o desenvolvimento territorial de Anã. Há ainda aqueles que não envolvidos com o projeto de TBC, também anseiam por estes objetivos, contudo não pretendem se envolver com 0 projeto.

Apesar da atuação da ONG como agente hegemônico no processo, não podemos deixar de considerar a atuação do Estado em Anã. Como apontamos, em relação ao TBC, tanto em nível estadual como em nível municipal poucas ações ou nenhuma ação foram direcionadas ao projeto. No que se refere ao Estado, em nível Federal, as ações mostraram-se pontuais, contudo se configuram como uma ausência presente do Estado, pois através do Edital do Mtur no001/2008 financiou o projeto de TBC desenvolvido pela ONG PSA.

Contudo, constatamos que para além de uma ausência presente do Estado, se faz necessário uma maior atuação deste agente em relação ao TBC em Anã, principalmente em nível Municipal, levando em consideração a localização da comunidade, pois conforme apontamos, durante os 7 (sete) anos de existência do projeto, em nenhum momento ocorreu uma visitação a comunidade de Anã para conhecimento do projeto, bem como um planejamento de ações em parcerias com a ONG PSA ou com a própria comunidade. Por mais que a ONG apresente uma autonomia quanto as suas ações na comunidade, não podemos deixar de prescindir o papel e a importância do Estado no TBC desenvolvido em Anã. Além do que, é a partir do reconhecimento de experiências como esta, que será possível a elaboração de políticas públicas especificas a esta modalidade de turismo, bem como pautadas nas especificidades das populações tradicionais ou não, que buscam através do TBC, alternativas de geração de renda, permanência e o desenvolvimento de seus territórios.

\section{Referências}

BARRETO, E.B. Possibilidades e limites do turismo de base comunitária no Polo Tapajós/Pará: um estudo nos municípios de Santarém e Belterra. Trabalho de Conclusão de Curso (graduação em Geografia) - Licenciatura Plena e Bacharelado em Geografia. Universidade Federal do Pará, Oriximiná, 2012.

BRASIL. Presidência da República. Casa Civil. Subchefia para Assuntos Jurídicos. Decreto $\mathrm{s} / \mathrm{n}$ de 6 de novembro de . Cria a Reserva Extrativista Tapajós-Arapiuns, nos municípios de Santarém e Aveiro, no Estado do Pará, e dá outras providência. Diário Oficial da República Federativa Brasileira, Brasília, 6 de novembro de 1998. Disponível em: $<$ http://www.planalto.gov.br/ccivil 03> 
BARTHOLO, R. Sobre o sentido da proximidade: implicações para um turismo situado de base comunitária. In: BARTHOLO, R; BURSZTYN, I; SANSOLO, D. Turismo de Base Comunitária: diversidade de olhares e experiências brasileiras. Ed. Letra e Imagem, 2009.

BURSZTYN, I. Desatando um nó na rede: sobre um projeto de facilitação do comércio direto do turismo de base comunitária na Amazônia. - Rio de Janeiro: UFRJ/COPPE, 2012. VIII, 243 p.: il.; 29,7 cm. Orientador: Roberto dos Santos Bartholo Júnior. Tese (doutorado) - UFRJ/ COPPE/ Programa de Engenharia de Produção, 2012.

CASTRO, I. E. Geografia e política: território, escalas de ação e instituições. 2a ed. Rio de Janeiro: Bertrand Brasil, 2009.

CASTRO, C.A.T.; NASCIMENTO, F.P. Regionalização do turismo no Estado do Pará. In:ENCONTRO NACIONAL DE GEÓGRAFOS, 17., 2010. Anais... Disponível

em: $<$ http://www.agb.org.br/evento/download.php?idTrabalho=2708>. Acesso em: 12 nov. 2011

CORIOLANO, L.N. O turismo comunitário no nordeste brasileiro. In: BARTHOLO, R; BURSZTYN, I; SANSOLO, D. Turismo de Base Comunitária: diversidade de olhares e experiências brasileiras. Ed. Letra e Imagem, 2009, pp.277-288.

CORIOLANO, L. N. O desenvolvimento voltado às Condições Humanas e o Turismo. In.: CORIOLANO, L.N; LIMA, L.C. (Org.). Turismo Comunitário e Responsabilidade Socioambiental. Fortaleza: EDUECE, 2003, pp. 26-46.

COSTA, W.M. Geografia Politica e Geopolítica: Discursos sobre 0 Território e o Poder. 2 ed. 2 reimpr. São Paulo: Edusp, 2013.

COUTINHO, Joana A. ONGs: caminhos e (des)caminhos. Lutas Sociais (PUCSP), São Paulo, v. 13/14, p. 57-65, 2005.

CRUZ, R.C.A. Turismo, produção do espaço e desenvolvimento desigual: para pensar a realidade brasileira. In: BARTHOLO, R; BURSZTYN, I; SANSOLO, D. Turismo de Base Comunitária: diversidade de olhares e experiências brasileiras. Ed. Letra e Imagem, 2009, pp. 92-107.

HARVEY, D. O novo imperialismo. 7. ed. São Paulo: Edições Loyola, 2013.

HARVEY, D. A produção capitalista do espaço. São Paulo: Annablume, 2005.

INSTITUTO CHICO MENDES DE CONSERVAÇÃO DA BIODIVERSIDADE. Plano de Manejo da Reserva Extrativista Tapajós-Arapiuns. ICMBio, Santarém, 2014.

IRVING, M.A. Reinventando a reflexão sobre turismo de base comunitária. In: BARTHOLO, R; BURSZTYN, I; SANSOLO, D. Turismo de Base Comunitária: diversidade de olhares e experiências brasileiras. Ed. Letra e Imagem, 2009, pp. 108-121. 
LANDIM, L. A Invenção das ONGs: Do serviço invisível à profissão impossível. Tese de doutoramento apresentada ao Programa de PósGraduação em Antropologia Social do Museu Nacional e da Universidade Federal do Rio de Janeiro. Rio de Janeiro, 1993. Disponível em: http://empreende.org.br/pdf/ONG\%27s,\%200SCIP\%27S\%20e\%20Terceiro \%20Setor/A\%20inven\%E7\%E30\%20das\%20ONGs.pdf. Acesso em Agosto de 2014.

MALDONADO, C. Fortaleciendo redes de turismo comunitário. In: @local.glob - número 4, 2007, pp. 8-14.

MARIANO. K. P. Globalização, integração e o estado. Lua Nova: Revista de Cultura e Política, №.71, São Paulo, 2007.

MITRAUD, S. (Org.). Manual de ecoturismo de base comunitária: ferramenta para um planejamento responsável. Brasília, DF: WWF Brasil, c 2003.

NEDER, R.T. As ONGs na reconstrução da sociedade civil no Brasil. Ciência \& Ambiente, v. 89, n.6, p. 42-50, Petrópolis, 1995.

PARÁ. Governo do Estado. Ações para o incremento do turismo no Estado do Pará. Belém: PARATUR; THR, 1998.

PARÁ. Governo do Estado. Plano de desenvolvimento do turismo do estado do Pará (PDT-PA). Belém: PARATUR; THR, 2001.

PARÁ. Governo do Estado. Plano Estratégico de Desenvolvimento do Turismo do estado do Pará. Belém: PARATUR, 2011.

SANCHO, A; IRVING, M.A. Tendências de inclusão social no Plano Nacional de Turismo 2007/2010: uma interpretação preliminar. Geografias Artigos Científicos. Belo Horizonte, 07(1) janeiro-junho de 2011, pp. 44-57.

SANSOLO, D. Centralismo e participação na proteção da natureza e desenvolvimento do turismo no Brasil. In: BARTHOLO, R; BURSZTYN, I; SANSOLO, D. Turismo de Base Comunitária: diversidade de olhares e experiências brasileiras. Ed. Letra e Imagem, 2009, pp. 122-141.

SANSOLO, D; BRUSZTYN, I. Turismo de base comunitária: potencialidade no espaço rural brasileiro. In: BARTHOLO, R; BURSZTYN, I; SANSOLO, D. Turismo de Base Comunitária: diversidade de olhares e experiências brasileiras. Ed. Letra e Imagem, 2009, pp. 142-161.

SANTOS, M. Metamorfoses do espaço habitado. São Paulo: Hucitec, 1991.

SANTOS, M. A natureza do espaço: técnica e tempo, razão e emoção. 4 ed. 5 reimpressão. São Paulo: Edusp, 2009a.

SANTOS, M. Pensando o Espaço do Homem. $5^{\mathrm{a}}$ ed. 2 reimpr. São Paulo: Editora da Universidade de São Paulo, 2009b.

SANTOS, M. Por uma outra globalização: do pensamento único à consciência universal. 18 ${ }^{\mathrm{a}}$ ed. Rio de Janeiro: Record, 2009c.

SANTOS, M. O Espaço do cidadão. $7^{a}$ ed., 1 reimpr - São Paulo, 2012a. 
SANTOS, M. Da Totalidade ao Lugar. $1^{\text {a }}$ ed., 2 reimp. São Paulo: Editora da Universidade de São Paulo, 2012b.

SANTOS, M. Por uma Geografia Nova: Da crítica da Geografia a uma Geografia Política. 6 ed., 2. Reimp. São Paulo: Editora da Universidade Federal de São Paulo, 2012c.

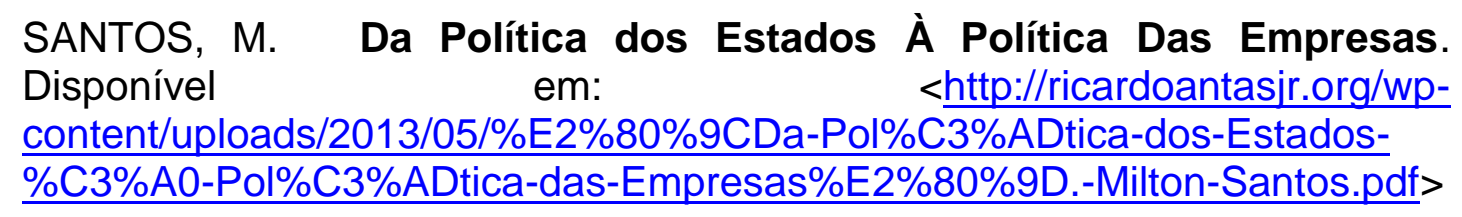

SANTOS, M.; SILVEIRA, M.L. O Brasil: território e sociedade no início do século XXI. Rio de Janeiro: Record, 2008.

SEEMANN, J. «Friedrich Ratzel entre Tradições e Traduções », Terra Brasilis (Nova Série) [Online], 1| 2012, posto online no dia 06 Novembro 2012, consultado $0 \quad 25$ Fevereiro $2015 . \quad$ URL: <http://terrabrasilis.revues.org/180>; DOI: 10.4000/ terrabrasilis. 180.

SILVA, K.T.P.; RAMIRO, R.C.; TEIXEIRA, B.S.; Fomento ao turismo de base comunitária: a experiência do Ministério do Turismo. In: BARTHOLO, R; BURSZTYN, I; SANSOLO, D. Turismo de Base Comunitária: diversidade de olhares e experiências brasileiras. Ed. Letra e Imagem, 2009, pp.359-373.

SILVEIRA, M. L. O Brasil: território e sociedade no início do século 21 - a história de um livro. ACTA Geográfica. Boa Vista, Ed. Esp. Cidades na Amazônia Brasileira, 2011. pp.151-163.

TODESCO, C. Estado e produção terceirizada da política pública de turismo para a Amazônia Legal. Tese (Doutorado em Geografia - Geografia Humana) - Universidade de São Paulo, Conselho Nacional de Desenvolvimento Científico e Tecnológico. Orientador: Rita de Cássia Ariza da Cruz. São Paulo, 2013.

TODESCO, C. Estado e terceiro setor na organização do espaço para o turismo no Vale do Ribeira. São Paulo: Departamento de Geografia da Faculdade de Filosofia, Letras e Ciências Humanas da USP, 2007 (Dissertação de Mestrado).

ZAOUAL, H. Do turismo de massa ao turismo situado: quais as transições? In: BARTHOLO, R; BURSZTYN, I; SANSOLO, D. Turismo de Base Comunitária: diversidade de olhares e experiências brasileiras. Ed. Letra e Imagem, 2009, pp. 55-75.

\section{Notas:}

${ }^{1}$ http://media.unwto.org/es/press-release/2014-01-20/el-turismo-internacionalsupera-las-expectativas-con-52-millones-llegadas-a. Acesso em 29 de Janeiro de 2014.

2 Turismo responsável é aquele que mantém e, onde possível, valoriza as caraterísticas dos recursos naturais e culturais nos destinos, sustentando-as para as futuras gerações de comunidades, visitantes e empresários.

Revista Brasileira de Ecoturismo, São Paulo, v.10, n.3, ago-out 2017, pp. 579-611. 
${ }^{3}$ World Wildlife Fund - Fundo Mundial da Natureza.

${ }^{4}$ A Rede Tucum é um projeto pioneiro de turismo comunitário no Ceará [...] formada por comunidades localizadas na zona costeira cearense. Atualmente, conta com a participação de dez comunidades costeiras, entre indígenas, pescadores e moradores de assentamentos rurais, dois pontos de hospedagem solidária em Fortaleza, além de duas ONG'S que fazem o apoio institucional à rede - Instituto Terramar (Brasil) e Associação Tremembé (Itália). (http://www.tucum.org/oktiva.net/2313/secao/18723)

${ }^{5}$ No site do Projeto Bagagem consta que a primeira expedição ocorreu no ano de 2002 (http://www.projetobagagem.org/).

${ }^{6}$ O Projeto Bagagem é uma iniciativa sem fins lucrativos que promove o turismo comunitário em regiões do Brasil que apresentam um grau significativo de organização comunitária. Por meio de viagens, o projeto leva um grupo de pessoas interessadas em conhecer melhor o país, para conviverem de maneira direta com a população local. Mais do que visitar atrações turísticas, a ideia é dar aos visitantes a oportunidade de experimentarem a vida nas comunidades como ela realmente é, em um processo de aprendizagem e intercâmbio cultural, onde participantes e membros das comunidades saem ganhando. A viagem é também uma oportunidade de conhecer o trabalho da ONG parceira e fonte de renda para as comunidades (http://www.projetobagagem.org/).

${ }^{7}$ Referência ao ano de 2014.

8 O Núcleo Oikos é uma associação sem fins lucrativos, criada em abril de 2008 para realizar investimento social privado com foco em iniciativas que integrem meio ambiente, cultura e geração de renda. Sua área territorial de atuação é na Amazônia e no Vale do Ribeira. A parceria com a ONG PSA ocorre desde o ano de 2007, apoiando o Projeto Arapiuns, cujas ações se inserem no contexto do Programa de Desenvolvimento Territorial - Empreendimentos Sustentáveis de Geração de Renda do Projeto Saúde \& Alegria, que estimula o ecoturismo de base comunitária e a produção artesanal juntamente com iniciativas de segurança alimentar, agroecologia e outros componentes estratégicos para a conservação de florestas, geração de renda e desenvolvimento regional (http://nucleooikos.org.br/).

Elcivânia de Oliveira Barreto: Secretaria Municipal de Planejamento, Desenvolvimento e Turismo de Santarém, Santarém, PA, Brasil.

E-mail: vaniabarreto21@gmail.com

Link para o currículo Lattes: http://lattes.cnpq.br/2580025480478892

Maria Goretti da Costa Tavares: Universidade Federal do Pará, Belém, PA, Brasil.

E-mail: mariagg29@gmail.com

Link para o currículo Lattes: http://lattes.cnpq.br/7796891525258446

Data de submissão: 10 de novembro de 2016

Data de recebimento de correções: 21 de junho de 2017

Data do aceite: 21 de junho de 2017

Avaliado anonimamente 